\title{
Challenges and Lessons Studying Non-timber Forest Products with Traditional Communities in the Amazon
}

\author{
Campbell Plowden
}

\section{Travel Log \\ Introduction}

Learning how to do publishable quality scientific work is not easy under any circumstances; learning how to do it in a different culture, language and environment makes the learning curve even steeper. While it is perhaps understandable that researchers try to publish only the successful parts of their work in scientific journals, this process filters out important stories about non-scientific challenges and failures. My experiences studying non-timber forest products (NTFPs) with the Tembé Indians and other people in the Amazon have taught me many things that I could not condense into any conventional paper. I will present some of these thoughts here in the hope they might be valuable to other researchers.

\section{Getting Started}

After working on the political side of tropical forest conservation for five years, I wanted to find a way to make a difference working directly in the Amazon rainforest. The problems of deforestation were well known, but practical solutions to address them at the local level were elusive. One promising strategy being tried in Brazil was assisting rubber tappers to sustainably harvest and sell other nontimber forest products (NTFPs). While indigenous people were widely recognized as the masters of knowledge about using plants for food, medicine and other purposes, few efforts were aimed at helping them use their expertise to improve their livelihoods and strengthen conservation. As I contemplated a dissertation topic, I most wanted to conduct a study on the ecology, management and marketing of NTFPs with an indigenous group in the Brazilian Amazon.

One of the primary official challenges of doing scientific research in many tropical countries is obtaining the necessary authorizations to gather data from human communities and to collect biological specimens. Obtaining this permission can often lead one into the midst of a classic Catch-22 situation. One is not supposed to do research without getting the proper authorizations, but it often feels like one cannot provide sufficient information to get these authorizations without making some contacts and doing some research.

I approached this challenge by making a scoping trip to Brazil in the spring of 1993. Working through the office of the government Indian agency, National Foundation of the Indian (FUNAI) in Belém, I arranged to visit several villages in the northern section of the Alto Rio Guamá Indigenous Reserve - the main homeland of the Tembé Indians. Walking through the forest with their expert guides further stimulated my desire to study NTFPs with an indigenous group, but this did not seem the right place to do it since their priority was finding help to expel illegal loggers and colonists who were destroying their land. All I could offer was a pledge to consider ways I might help. At night, their foot stomping, maracá shaking, and resonant voices chanting "Araruna" (blue macaw) burrowed into my psyche. When I went home, the rhythm played

\section{Correspondence}

Campbell Plowden, Center for Amazon Community Ecology, 1637 B North Atherton St. \#90, State College, PA 16803.

cplowden@comcast.net

Ethnobotany Research \& Applications 6:023-028 (2008) 
over and over in my head as I struggled to remember its proper lyrics.

My relationship with the Tembé took a big step forward in 1996 when I helped host a young leader to do a speaking tour in the U.S. He liked my ideas for studying NTFPs and invited me to his village on the Gurupi River in the southern end of the reserve. Unlike the part of the reserve I had first visited, this region still had bountiful intact forests. His people were, however, keen on finding ways to increase local income through sustainable use of their forest resources. I spent six weeks in Tekohaw village that summer doing a pilot study of copaiba oleoresin production that marked my honeymoon period with the group. I spent most of my time in the forest with four or five elders whose intimate knowledge of medicinal plants, bird calls, and trails was every bit as impressive as any group I had read about. The prospects for harvesting copaiba in this area as a new economic resource were not promising, but our partnership felt good, and we were enthusiastic about exploring other products in the future. The day before I left, the chief took me on a bit of a "real estate" tour of the village, and we agreed that the village would renovate an abandoned house for my family when we came the following year. The other important accomplishment of this summer was finding a professor at the agricultural university in Belém to serve as my scientific counterpart for the research visa I would need to launch a longer term study.

Going this next step wasn't so easy. Although my summer trip had given me ample information to formulate a good proposal, establish a good relationship with a host community and obtain academic sponsor, the process to secure the research visa was arduous. The application required approval by the National Council of Scientific Development and Technology $(\mathrm{CNPq})$, the Brazilian Institute of Environment and Renewable Natural Resources (IBAMA), FUNAI, three independent scientists, and the Minister of Technology. This took "only" nine months because I spent hundreds of dollars in phone calls to Brasília pleading with various officials to move my application on to the next person. Due to concerns about biopiracy, Brazil's conditions for doing research concerning biodiversity have become even more stringent since my visa was approved in 1997.

I am now working in Peru where research visas are not required, but the natural resource agency, National Institute of Natural Resources (INRENA) does require separate permits to collect and to export plant and animal specimens. Getting the collection permit was very efficient, but exacting requirements to export specimens has left me unable to have my samples examined by taxonomic experts for two years. Great patience and persistence are needed to deal with these challenges.

\section{Trying To Stay Healthy In The Jungle}

The most important thing I neglected to bring with me into the field on my first trip to the Amazon was a blanket. Shivering in my hammock for several nights with nothing but a borrowed thin sheet wrapped around me was a lesson I didn't need to learn twice. During my stay with the Tembé in the summer of 1996, I discovered the next important lesson about jungle living. Mosquito bites are annoying, but generally fade away if left alone. Biting flies, however, generated welts that itched so intensely and for so long that I scratched them until they were bloody. My failure to adequately clean these wounds led to them becoming infected with a Staphylococcus bacteria. By the time I left the reserve I had badly swollen ankles and a low grade fever that needed strong antibiotics to treat.

Before my family left for a year of living in the field, we got every immunization required or recommended and brought a small pharmacy's worth of prescription and over-the-counter drugs with us. I rubbed andiroba oil as a natural insect repellent on exposed parts of my skin every day before going into the forest. My family's most well read book during our time in the village was "Where There is No Doctor" (Werner et al. 1992). We drank only water that had passed through our ceramic filter and adopted an evening first aid ritual of treating each others' bites and scrapes with alcohol, Mercurochrome, and antibiotic ointment. We kept mosquitoes at bay at night by surrounding our hammocks with netting, and when chiggers slipped through the fine mesh we liberally rubbed our bellies with calamine lotion and hydrocortisone cream.

Tembé neighbors showed us how to pluck burrowing fleas from tender toe areas with an orange tree spine before they festered. One day my wife and daughter removed several hundred tiny ticks from my body after I had unknowingly stumbled into a nest of them in the forest. Other nasty encounters with invertebrates included wasp stings, ant bites, and accidentally squishing a venomous hairy caterpillar on my arm. Tall rubber boots saved my field crew and me several times from poisonous snake bites, and I felt fortunate not to get malaria when many others in the village did. My body was not always strong enough or well adapted to the environment, though, and I periodically got sick with a fever or malaise of unknown origin that caused me to miss days in the field. I left the village for a whole month once when bad headaches and joint pain became an unrelenting part of my day. After a battery of blood tests in Brazil and the U.S., an infectious disease specialist could only speculate that I had an exotic arbovirus with no known treatment. I finally recuperated after a few months at home with a regime of a cleansing diet, herbal supplements to fight parasites and strengthen my immune system, and regular sessions of yoga and visits to a holistic chiropractor. I loved this field work as much 


\section{Plowden - Challenges and Lessons Studying Non-timber Forest Prodcuts with Traditional Communities in the Amazon}

as anything l've ever done, but taking care of my health in this climate required a lot of vigilance.

\section{Logistics, Communication and Technical Challenges}

Doing research in primary tropical forests almost by definition requires working in remote places because most places that are easy to get to have been significantly altered. Traveling from Belém to my field site at Tekohaw was almost always a saga. Scheduling a trip to the reserve took two days to two weeks. It usually began with a four hour bus ride from the city to a town by the Gurupi River. We then usually spent one or two nights in a rickety store room until a boat arrived and was provisioned before returning upriver. The trip to Tekohaw could take as few as six hours in an open motorboat if the engine didn't conk out. One trip from the village downriver took four hours longer because our gasoline ran out. We finally reached the town at night after paddling the last three hours with a bowl. Going by covered motor launch kept one dry during the rainy season, but it meant spending 12 to 24 hours in transit with the constant noise and fumes of a diesel engine. Travel during the dry season was particularly tricky since boats had to navigate through rocky rapids. Several boats capsized in the process. Tekohaw eventually built its own airstrip, but chartering a private plane for this one hour trip costs about $\$ 800$, so I took whatever boat was available and did my best to protect equipment for whatever might happen on the way. A road has now been built to the village. This has made it easier for both Indians and illegal loggers to come and go through the reserve.

Once I made it into the village, it was not easy to communicate with anyone outside it. The life line of Tekohaw to other villages and FUNAI is a ham radio. Leaders checked in with each other daily to share news, pass along requests for transportation, and arrange meetings. Once a month or so I could send out a letter with someone going to the city or receive mail brought in by the FU$\mathrm{NAl}$ agent. I looked into satellite phones but the licensing procedure and costs were prohibitive. After my family had gone home during my second year in the reserve, I periodically listened to British Broadcasting Corporation (BBC) International on a short-wave radio, but once I was in the reserve I pretty much had to accept that I was not going to communicate with the rest of the world for six to eight weeks. It was relaxing in many ways to be relieved of the daily burden of violence in the world, but the isolation from my family became increasingly hard.

My brand of ecological field work fortunately did not need a lot of sophisticated equipment. I brought standard 50 meter measuring tapes, tree diameter tapes, compasses, tree tags and Global Positioning System (GPS) units from the U.S., and I easily got basic tools like machetes, hammers, drills in Belém hardware stores. Accidental machete cuts through measuring tapes were remedied with duct tape. Setting up my house as a laboratory and office that could function at night was a bigger challenge. My unbreakable solar panels worked flawlessly for years, but I went through three expensive car batteries before I finally worked out (with the help of a digital voltmeter) how to budget my energy consumption for a couple of compact fluorescent light bulbs, a laptop computer and portable printer. I did without the computer for the first few months since its screen was damaged in the first boat trip to the reserve, but once it was repaired, it became a vital tool for creating data collection sheets, entering data, and writing reports in the field. Documenting my work, life in the village and critters in the jungle with cameras was a great pleasure, but there are even fungi in the humid forest that eat and etch their way through the plastic coating on lenses. Keeping electronic gear in dry bags with silica desiccant became an essential practice in later trips.

\section{Blending Indigenous Knowledge With Scientific Inquiry}

I intentionally wanted to study NTFPs with indigenous people because I believed that I could learn a lot more about these plants working with people who were familiar with them than if I simply set off with a tape measure into a pristine area of forest by myself. It took less than a few days to confirm that my Tembé colleagues knew more about the forest they had grown up in than I could learn in my lifetime, but I was eager to learn as much with them as I could. It took a good bit longer to realize that their understanding and beliefs did not always translate well into my desire to assign numerical values to some things or describe natural history relationships in western biological terms. One lesson was learning how to gauge the response to a question about the abundance of a particular plant or how much product it typically yielded. Beginning with the copaiba work, the Tembé elders I first worked with assured me that we would find lots of trees and told me about times when they had filled large cans with oleoresin. It was rather sobering to them and me when it took several weeks of daily searching to find just 50 trees and that we only gathered a few liters of oleoresin from drilling most of them.

Another lesson I learned working in the villages was that the level of skills and knowledge varied dramatically between individuals. Some people were very adept at finding certain kinds of trees, but not others. Elders could generally identify hundreds of types of trees but were unable to read, write or count higher than ten. Younger men generally recognized fewer trees than the elders, but a few were quick to learn how to read instruments and reliably record the measurements on data sheets. Research teams for any given NTFP almost always had people with a blend of these skills, so the research could provide opportunities for cross-generational learning and appreciation. 
When I started asking about "breu" (pronounced brayyoo) resin, Tembé collectors told me about the "tapuru" (larvae) they found in the lumps and related stories about filling entire sacks of resin from single trees. As the research progressed, it became apparent that the Indians' observation of the "tapuru" was fundamental to the resin's formation, and we proceeded to probe this relationship in great detail. On the harvest side, it again became apparent that the huge yields people described were the result of their best days, not their normal ones. This reinforced the recommendation by Grimes et al. (1994) that estimates of NTFP harvest amounts obtained through ethnobotanical inquiry be followed up with actual production studies in order to develop reliable quantitative estimates.

The most culturally challenging situation I confronted related to work in the field involved the regeneration of titica vine roots. One Tembé elder told me that the slender titica vines climbing some host trees were a different kind of vine than the ones whose aerial roots were harvested. Other Tembé told me that these aerial roots were created when the legs of certain dead ants become elongated. I was skeptical about the Indian version of titica regeneration, but I tried to keep an open mind and wondered if ants might play some role in the germination of titica seeds in the canopy. I later found out that many Amazon groups make a connection between dead ant legs and vine regeneration. What they have probably observed are the hyphae of a Cordyceps fungus that have emerged from ants they have infected and killed. These hyphae do bear a resemblance to the anchor roots on the stems of young climbing titica vines. When I harvested several whole plants at a different site, it was apparent that its diminutive fruits were well hidden from view on the ground. I regret that I did not harvest some plants with the Tembé since these could have provided a concrete example to discuss what I felt awkward saying based on book knowledge. Native lore is an important part of a group's culture, but I do believe that harvesters who understand a vulnerable plant's regeneration will be better able to regulate its harvest to preserve the resource for the future.

\section{Expectations Of A Researcher}

Working with the Tembé provided me an opportunity to learn about the forest in ways I never could have done on my own and gave me some of the best and worst experiences of my life. Many of these successes and disappointments relate to the fact that my relationship with the community went far beyond my role as a researcher studying NTFPs. As mentioned earlier, my initial contact with Tembé from the Gurupi River villages occurred in the U.S. when I escorted a leader on a 10-day long tour of the U.S. that gave him many opportunities to discuss his people's needs in the areas of health care, education and land rights. I was welcomed to Tekohaw not just as someone who would study the economic potential of a few plants but as someone who would be an active participant in many aspects of village life and concerns. For the better part of four years, I was known to everyone in the community as "Zui'zu" (white frog). I was determined not to be another scientist who came into the community, gathered whatever data and materials he wanted and left without giving much in return.

I tried to help direct resources to the Tembé community in various ways. I was very grateful to the members of State College Friends Meeting and its Tembé Indian Support Committee for their tremendous assistance in this area. This committee secured several large donations and did fundraising projects that included: young children making and selling buttons they made with Indian designs, older children making dinner and offering babysitting services, and all children selling flower bulbs. I bought and traded for Tembé handicrafts in the village and sold them at the Friends Meeting and at slide shows I did about the Tembé in the United States (U.S.). I arranged for a Tembé leader from Canindé village to attend an Amazonian indigenous conference in New York and recruited five people from the U.S. to attend a traditional festival in the reserve in return for a donation to the community. I obtained donations of clothing, hand tools, medical and school supplies, soccer balls and sports equipment for six Indian villages along the Gurupi River. Funds raised in these projects were used to finish construction of a large wooden launch, buy a new motorboat and diesel engine, repair two gasoline engines, produce a book of 200 traditional Tembé chants in Tembé and Portuguese, finance a land rights project and complete a cultural house.

While living in the village I tried to contribute to the community by bringing in fish hooks, fishing line and ammunition for trade. I loaned out my tools, fixed broken water pipes, tended sick children, took family photos, and gave evening classes in math, geography, science, and environmental advocacy. When I left the village I gave my solar panels, furniture and remaining first aid and paper supplies to the schools and infirmaries of three different villages.

Trying to get my research done and be a good employer presented many challenges. The first summer in Tekohaw the elder Tembé worked with me without formal wages, but at the end of the summer they each made a list of items they wanted from the city in compensation for their time. I initially liked this system because it felt more like a cooperative venture than a business arrangement, but it was not fair because a few people who worked little wanted more than others whose daily efforts were integral to the project. When I returned in 1997 I paid everybody who worked with me the same amount for each day they worked and raised this amount every year. This system in general worked well, but there was social pressure to hire as many people as possible. This was difficult because my funds were limited, and I mostly needed people who 


\section{Plowden - Challenges and Lessons Studying Non-timber Forest Prodcuts with Traditional Communities in the Amazon}

either knew forest trees very well, could read and write numbers well or both. At one point I created a special project to measure manioc productivity more as a way of paying some extra people than because the information was vital to my research goals.

I strove for an elusive balance between firmness and flexibility in dealing with research needs versus other needs of the village and my helpers. I got very little work done in the fall of 1997 because most men were away from the village cutting boundary lines for the reserve. Shortly after they came back they all got engaged in the 10-day long St. Benedict's Festival. I had to plead with the community to release a few people to me or I would not be able to accomplish anything. A year and a half later the situation was reversed. I sometimes had four crews of people going out on the same day to get production data on andiroba, breu, amapá and copaiba. It seemed wonderful until the chief came to me and asked me to release some of these men so they could work on the community garden and building projects. It became apparent that while many people appreciated the opportunity to work, the community was suffering because their desire to do work for the community for free had begun to wane. Some of these people at least willingly made donations to a travel fund for the leader when there was an important meeting for him to attend in Belém or Brasília.

Taking on such a broad range of research topics had other consequences for my work and relationships. By trying to gather production data about so many plants during a two-year period, I inevitably sacrificed gaining a deeper understanding of a few of them. Over time, I became more of a field manager than an ecologist building my insights through daily observations in the field. Part of this seemed unavoidable since there were many days when I felt too weak or sick to go in the forest, but this mode gradually altered my relationship with my Tembé field assistants. I knew next to nothing about the forest, but when I faced the mud, bugs, poisonous snakes, rain and shared one can of sardines with them for lunch I initially earned their respect. When I stayed in the village more often during the day, I had fewer chances to personally share their successes and travails in the forest. My interactions with them became more focused on checking data sheets and paying their wages. Our relationship had uncomfortably shifted from partners and friends to employer and employees.

By the end of 1999, it was clear that the expectations the community had of me were more than I could meet. By hiring people from one family in Tekohaw, other families sometimes felt slighted if I did not hire someone from theirs. Since I lived in Tekohaw it was natural that I hired mostly people from there and provided other types of assistance to that community. This made some people in the other Tembé villages upset that I was not paying more attention to them. Since my field work was carried out exclusively in Tembé villages and fundraising projects brought benefits mostly to them, the Ka'apor Indian villages on the other side of the Gurupi River began to feel increasingly angry that I was unjustly ignoring them. I was aware that such feelings could arise and tried to deal with it by hiring representatives from several villages to work in projects at Tekohaw, but it was difficult for people with families to stay away from their home villages for long. I did one well-received side project in Cajueira village, but it was not possible to do so in others without fracturing ongoing research at Tekohaw. Boats and boat equipment were theoretically used by all of the villages, but over time, each village wanted their own craft. I tried to channel funds earmarked for a land right's project to a committee of village leaders, but the delay in releasing funds due to inter-village politics led to recriminations against me by individual villages who wanted me to release the funds directly to them.

I did one round of visits to all of the Gurupi villages to explain the goals of the research project and did regular updates at Tekohaw. It was evident, however, that even at Tekohaw the level of understanding of all of these studies was not very high. The simplest explanation was that I was studying plants that might lead to additional sources of income, and I used the most creative ways I could think of to convey quantitative concepts to people who knew little or no math. When the research began to show that the new products being investigated were not very promising in this respect, it became harder to explain to most people why continuing such studies were still important or relevant to them. Information on some study trees was lost because people removed numbered tags or harvested trees for themselves in between research harvests. Some people who worked with me took a genuine interest in probing topics like the relationship between the breu resin and the weevil larvae that lived in it, but many young men worked with me mostly because it was a relatively easy and interesting way to make some money. My family was warmly embraced, but I believe most of the village accepted me as a friendly foreigner with quirky interests and were content with my presence as long as I provided some tangible benefits to the community on a regular basis. The increasing interest that people had in making money seemed to fuel speculation that I hoped to get rich taking photos, recording chants and collecting plants around the village. These issues were periodically discussed, but it became increasingly difficult to work without unspoken suspicions and jealousies clouding many interactions. By the time I returned to Brazil in the spring of 2000 to wrap-up field work for my dissertation and to present some preliminary research results, the cord of trust between several villages and me had badly frayed. I left with my head high but a very heavy heart.

Indigenous people have an understandable expectation that researchers they welcome to their communities will carry out their work with full consultation, conduct themselves with integrity and fairly compensate people who work with them and the villages that host them. These 
were my expectations going into this project, but it is apparent I needed to communicate more openly and realistically about these subjects more often. My dialogue with leaders sometimes worked and sometimes did not because I had to operate in the context of intra- and intervillage politics that were often beyond my understanding or control. I could speak Portuguese well enough to do my work in the forest and conduct daily life in the village, but at times I was simply unable to communicate effectively about complex and sometimes volatile emotional and cultural issues because I couldn't use my native language.

I admit that for a time I enjoyed the feeling that I could do fascinating work in the forest and make contributions to the community in so many ways. The needs of the people seemed deep and diverse, and they stimulated creative energies to help however I could. Trying to be a researcher, medic, teacher, employer, banker, fundraiser, archivist, handicraft buyer, hardware supplier, father and husband were too many roles to keep up for the long haul. My inability to balance these roles led me to make mistakes that hurt my relationship with some members of the community. The cumulative weight of these roles almost stretched the patience of my family and my health to their breaking points.

The issue that I will ponder long and hard as a result of my time with the Tember is the role of money in the community. I was initially attracted to studying the economic potential of NTFPs because I thought that increasing revenue would help the community to improve health care, education and support forest protection. Over time these beliefs were strained or vanished. Most people wanted "modern" medicines because they had lost some of the knowledge or faith to use rainforest plants, but they didn't want to spend their money on these things because they expected the government to supply them. The Tember wanted to have Tembé teachers in their schools, but they consistently failed to honor commitments to compensate the local people who devoted long hours to teaching the village children. Young leaders were unanimously praised for their efforts to defend their land rights, but raising donations from the community to send these people to important meetings was a perennial struggle. People had not abandoned their desire to help the welfare of their community, but they clearly chose to spend most or all of what little money they made on material goods for their family. The appeal of cooking food with a clean flame from a gas stove instead of cutting fire wood, making charcoal and living in a soot-filled house is obvious. People needed cash to purchase certain foods and materials like salt and fish hooks to survive. Given my affluence as a middleclass American, it would be hypocritical to criticize anyone for wanting a new shirt or CD player, but I left with no illusions that increasing village income would necessarily improve Tembé health and education, preserve its traditional culture or save its forest. Money can sometimes play a vital role in supporting such objectives, but mechanisms need to be in place in the community to handle such funds in a constructive way. My feeling was that the struggle to accomplish these goals was being waged from people's hearts and didn't depend on how much money they had or the size of their radio.

When I returned to Brazil in 2004, I was sad to hear from various Tembé friends that illegal logging had spread to the southern part of the reserve and that some leaders had supposedly begun to accept payments from the loggers to keep quiet. Although other leaders vigorously opposed this collusion, it wouldn't be surprising if some had decided to seek some profit from these activities since the government had consistently shown they were unwilling or unable to keep the loggers out.

In spite of these challenges, I am beginning to work with other communities in the Amazon now through my work with the Center for Amazon Community Ecology. I even hope I re-establish enough trust to work with the Tembé again. I believe there is an important role that researchers can play in working with local communities to promote forest conservation and support rural community development. Researchers can continue to study the complexities of nature and help develop ways for people to coexist with the full diversity of a tropical ecosystem in a world where social and economic conditions are rapidly changing. Doing so will take a lot of patience, perseverance, commitment and humility.

\section{Literature Cited}

Grimes, A., S. Loomis, P. Jahnige, M. Burnham, K. Onthank, R. Alarcón, W. P. Cuenca, C. C. Martinez, D. Neill, M. Balick, B. Bennett, \& R. Mendelsohn. 1994. Valuing the Rain Forest: The economic value of nontimber forest products in Ecuador. Ambio 23(7):405-410.

Plowden, C. 2001. The ecology, management and marketing of non-timber forest products in the Alto Rio Guamá Indigenous Reserve (eastern Brazilian Amazon). Ph.D. dissertation, Pennsylvania State University. University Park, PA.

Werner, David, C. Thuman, \& J. Maxwell. 1992. Where There is No Doctor: A Village Health Care Handbook. Hesperian Foundation, Berkeley, CA. 